\title{
A new species of Ergasilus (Copepoda: Cyclopoida: Ergasilidae) from coastal fishes of the Mexican Pacific
}

\author{
Eduardo Suárez-Morales ${ }^{1}$ and Ana María Santana-Piñeros ${ }^{2}$ \\ ${ }^{1}$ El Colegio de la Frontera Sur (ECOSUR), Chetumal, Quintana Roo 77900, Mexico; \\ ${ }^{2}$ Universidad del Mar, Campus Puerto Angel, Oaxaca 70902, Mexico
}

Key words: Copepoda, Ergasilidae, Ergasilus davidi, copepod taxonomy, fish parasites, Tropical Pacific, Mexico, Chiapas

\begin{abstract}
A new species of the cyclopoid copepod genus Ergasilus von Nordmann, 1832 is described based on adult female specimens removed from the gills of the yellow snapper Lutjanus argentiventris (Peters) and the yellowfin snook Centropomus robalito Jordan et Gilbert from a Pacific coastal system of Mexico. The new species Ergasilus davidi sp. n. has a combination of characters that includes a two-segmented first leg endopod, a three-segmented fourth leg endopod, and the presence of a single seta on the first antennular segment. These characters are shared with 14 other congeners known mainly from Brazil and North America. It differs from these other species in the armature and ornamentation of legs 1 and 4, the shape of the body, and the structure and ornamentation of the antennae. Additional characters include a maxillar basis armed with blunt teeth, distally bent maxillular setae, and naked margins of first exopodal segments of legs 2-4. Previous regional records of Ergasilus sp. from both fish species are probably assignable to E. davidi. The prevalence and intensity of infection was estimated for both teleost species and agrees to previous data. Based on other records of the genus from several other teleost species in the surveyed area and adjacent zones of the Eastern Pacific, it is presumed that the new species could have a wider range of hosts. The new species represents the first Ergasilus described from Mexican waters of the Pacific. Overall, the genus remains poorly known in Central America and Mexico.
\end{abstract}

The copepod family Ergasilidae von Nordmann, 1832 is one of the major families of the Cyclopoida (Ho et al. 1992, Boxshall and Montú 1997) and is known to contain 26 genera of forms that are ectoparasites of teleosts in freshwater, brackish, and coastal marine waters (Amado et al. 1995, El-Rashidy and Boxshall 1999). There are over 260 known species within the Ergasilidae and most of them are found in freshwater environments. The genus Ergasilus von Nordmann, 1832 includes more than 180 species (Boxshall and Halsey 2004), some of them causing serious damage among cultured fishes (Lin and Ho 1998). Only the adult female ergasilids are parasitic (Amado et al. 1995); all pre-adult stages and the adult males are planktonic forms that can be captured during plankton surveys. In some instances the local density of these parasites favours the occurrence of adult females in the water column (Amado and Rocha 2001, Boxshall et al. 2002).

The knowledge of the ergasilid fauna in the Americas is markedly patchy. Some geographical areas have been surveyed intensively for many years; together with the North American ergasilid fauna, the Brazilian fauna in South America is probably the best known in the Americas (see Roberts 1970, Thatcher and Boeger 1983, 1984). However, Central America and Mexico represent a large continental area in which the ergasilid fauna remains practically unstudied.
The yellow snapper Lutjanus argentiventris (Peters) (Lutjanidae) and the yellowfin snook Centropomus robalito (Jordan et Gilbert) (Centropomidae) represent valuable resources along the Mexican coast of the $\mathrm{Pa}$ cific Ocean. The biology and parasitology of these and other tropical fish species is being studied in detail in different coastal systems (Moravec et al. 2007, Violante-González et al. 2007); one of these is the Chantuto-Panzacola lagoonal complex in the Mexican State of Chiapas. The parasite fauna of both teleost species was investigated and numerous specimens of an undescribed species of Ergasilus were collected. The new species is described and compared with the related species of this genus. Data are presented on the abundance, intensity, and prevalence of the infection.

\section{MATERIALS AND METHODS}

A total of 4080 adult female copepods were recovered from the parasitological examination of 50 specimens of $L$. argentiventris and 61 of $C$. robalito from the ChantutoPanzacola System, State of Chiapas, Mexico, between March 2006 and May 2007. Copepods were collected directly from the host by removing them from the gill arches with the aid of forceps under a stereomicroscope to avoid damaging the antennae. The specimens were fixed in $70 \%$ ethanol after a brief treatment with a saline solution. Some specimens were dissected under the stereomicroscope; drawings were prepared using a camera lucida mounted on an E-200 Nikon compound 
microscope. Copepod body and appendage terminology follows Boxshall et al. (2002). The use of ecological and infection rate indicators including abundance, intensity, and prevalence follows Bush et al. (1997). Type specimens were deposited in the collection of Zooplankton held at El Colegio de la Frontera Sur (ECOSUR), Unidad Chetumal (ECO-CHZ), Quintana Roo, Mexico, the Collection of Parasitic Helminths (ECO-PA) of the same institution, and the Institute of Parasitology, Academy of Sciences of the Czech Republic, České Budějovice, Czech Republic.

\section{DESCRIPTION}

Family Ergasilidae von Nordmann, 1832

Genus Ergasilus von Nordmann, 1832

\section{Ergasilus davidi sp. n.}

Figs. 1-3

Description of female: Total body mean length 1.92 mm (range: $1.72-2.2 \mathrm{~mm}, \mathrm{n}=15$ ) measured from anterior end of cephalothorax to posterior margin of anal somite. Prosome 5-segmented. Cephalosome robust in dorsal view, 1.4 times longer than wide (length: $1.1 \pm$ $0.3 \mathrm{~mm}$ in average); antennule and antenna visible in dorsal view. First pedigerous somite wide, nearly twice as long as second. Second to fifth pedigerous somites tapering posteriorly (Fig. 1B). Urosome comprising short fifth pedigerous somite, rounded genital doublesomite wider $(0.47 \mathrm{~mm}$ in average) than long (0.41 $\mathrm{mm})$, with row of spinules on dorsal and ventral surfaces, and three free somites. Anal somite incised medially, about as long as preceding somite, armed with row of spinules on ventral surface (Fig. 2C). Caudal rami subrectangular, almost twice longer than wide, armed with four setae, medial terminal one noticeably thicker than remaining caudal setae. Antennule 6-segmented, tapering distally, setal formula from proximal to distal segments: $1,11,5,3,2+1$ aesthetasc, $5+1$ aesthetasc (Fig. 2B). Antenna long, slender, 4-segmented, with short coxobasis plus 3-segmented endopod and strongly curved terminal claw. Coxobasis robust, surface finely pilose, otherwise unarmed. First endopodal segment slightly curved, about as long as succeeding segment, surface as in coxobasis, with hyaline, blunt process on subdistal position. Second endopodal segment curved, armed with strong spiniform, conical process on proximal $1 / 3$ of segment and minute distal seta. Terminal claw strongly curved, relatively long, about half the length of preceding segment, with proximal pilose patch (Fig. 1C). Mandible with anterior blade slender, with strong bristles along anterior margin; middle blade curved, armed with row of flat, foliose, distally curved teeth along posterior margin; third blade with row of blunt teeth on posterior margin, teeth larger distally, anterior margin naked. Maxillule represented by single lobe armed with couple of rigid setae on outer margin; both setae with bent tips. Maxilla comprising large tapering syncoxa, unarmed; basis short, represented by subrectangular lobe provided with array of strong, blunt teeth distally and subdistal row of spines (Fig. 2A).
Swimming legs 1-4 biramous; all legs 3-segmented, except 2-segmented first endopod and fourth exopod (Fig. 3 A-D). Legs 1-3 with outer margin of both rami furnished with rows of small spinules, except first exopodal segments of legs 2-4. Coxal plate of legs 1-4 wide, furnished with spinules arranged in irregular pattern (Fig. 3E). Basis of all legs bearing slender outer basipodal seta. First leg with endopod longer than exopod, latter reaching about half length of distal endopodal segment. First endopodal segment slightly longer than second segment, which bears large patch of strong spinules along inner surface; spinule array with mixed blunt and acute elements. Group of blunt spinules forming rosette-like array at mid-length, on lateral margin of segment; this cluster of spinules not clearly distinguishable in all specimens examined (see Fig. 2D, E). Inner apical spine of second endopodal segment 2.2 times longer than outer spine. Outer margin of both endopodal and exopodal segments of legs 2-4 with row of short setules except for smooth first exopodal segment of legs 2-4.

Spine and setal formula as follows:

$\begin{array}{lllll} & \text { Coxa } & \text { Basis } & \text { Exopod } & \text { Endopod } \\ \text { Leg 1 } & 0-0 & 1-0 & \text { I-0; 0-1; III,4 } & 0-1 ; \text { II,4 } \\ \text { Leg 2 } & 0-0 & 1-0 & \text { I-0; 0-1; I,6 } & 0-1 ; 0-2 ; \text { I,4 } \\ \text { Leg 3 } & 0-0 & 1-0 & \text { I-0; 0-1; I,6 } & 0-1 ; 0-2 ; \text { I,4 } \\ \text { Leg 4 } & 0-0 & 1-0 & 0-0 ; \text { I,5 } & 0-1 ; 0-2 ; \text { I,3 }\end{array}$

Fifth leg reduced, represented by single lobe armed with two unequal, smooth setae.

Male: Unknown.

$\mathrm{T}$ y $\mathrm{p}$ e $\mathrm{h}$ o s $\mathrm{t}$ : The yellow snapper Lutjanus argentiventris (Peters, 1869) (Lutjanidae, Perciformes). This species dwells in coastal and shelf areas of the Eastern Pacific, from the Gulf of California to Peru.

$\mathrm{O} \mathrm{t} \mathrm{h}$ e $\mathrm{r} \mathrm{h}$ o s t s : The yellowfin snook Centropomus robalito Jordan et Gilbert, 1882 (Centropomidae, Perciformes), a coastal and brackish water species, distributed between the Gulf of California to Colombia.

Site of infection: Gills of both hosts.

$\mathrm{T}$ y p e 1 o c a 1 i t y : Chantuto-Panzacola lagoon system $\left(14^{\circ} 43^{\prime}-15^{\circ} 40^{\prime} \mathrm{N}, 9^{\circ} 26^{\prime}-93^{\circ} 20^{\prime} \mathrm{W}\right)$, State of Chiapas, Mexican coasts of the Pacific Ocean.

E t y m o log y: This species is named after David GonzálezSolís for his solid contributions to the knowledge of the parasitic fauna of Mexico.

$\mathrm{H}$ o s t - p a r a s i t e d a t a : Prevalence of infection on $L$. argentiventris: $42 \%(\mathrm{n}=21)$; on C. robalito: $11.5 \%(\mathrm{n}=$ 7). Mean abundance on L. argentiventris: $80.9 \pm 144.6$; on C. robalito: $0.3 \pm 1.1$. Mean intensity on $L$. argentiventris: $192.7 \pm 168.2$; on C. robalito: $2.3 \pm 2.6$.

Mat e ri a 1 ex a min ed: Holotype female, undissected, ethanol-preserved, from $L$. argentiventris, vial deposited in ECO-CHZ003576; paratypes ECO-CHZ003577, 5 females, 2 undissected, from same host slide mounted in glycerine, sealed with Entellan ${ }^{\circledR} ; 4$ paratype females from same host, 

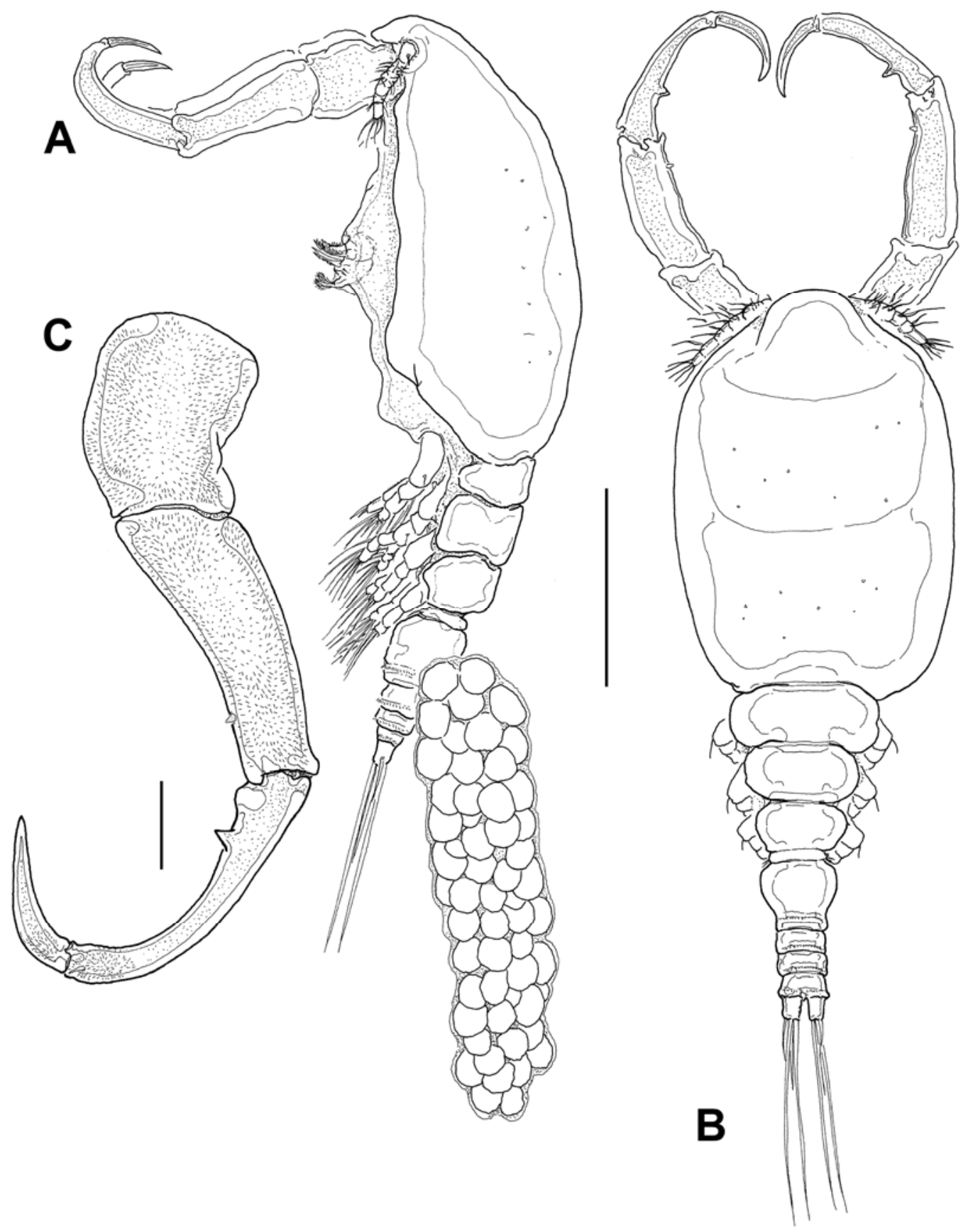

Fig. 1. Ergasilus davidi sp. n., adult female. $\mathbf{A}$ - habitus, lateral view; $\mathbf{B}-$ same, dorsal view; $\mathbf{C}-$ antenna. Scale bars: $A, B=400$ $\mu \mathrm{m} ; \mathrm{C}=50 \mu \mathrm{m}$.

two slides deposited in the Institute of Parasitology, Academy of Sciences of the Czech Republic, Czech Republic (Cat. No. Cr-9). Additional paratypes from C. robalito, 2 fe-males, undissected, semi-permanent slides mounted in glycerine, each deposited in ECO-CHZ003578 and ECOPA-055. Additional specimens, including numerous females in original samples, deposited in the Laboratorio de Necton and Parasitología, El Colegio de la Frontera Sur, Chetumal, Mexico and Universidad del Mar, Campus Puerto Angel, Oaxaca.

\section{Remarks}

The specimens examined were identified as belonging to the genus Ergasilus owing to their possession of the diagnostic characters described by Hewitt (1978) and Boxshall and Montú (1997), including a biramous leg 4 with a 2-segmented exopod and 3-segmented endopod, 6-segmented antennule, antenna with a single claw, reduced maxillae, and maxillipeds absent in females. The new species, E. davidi, shows a combination 


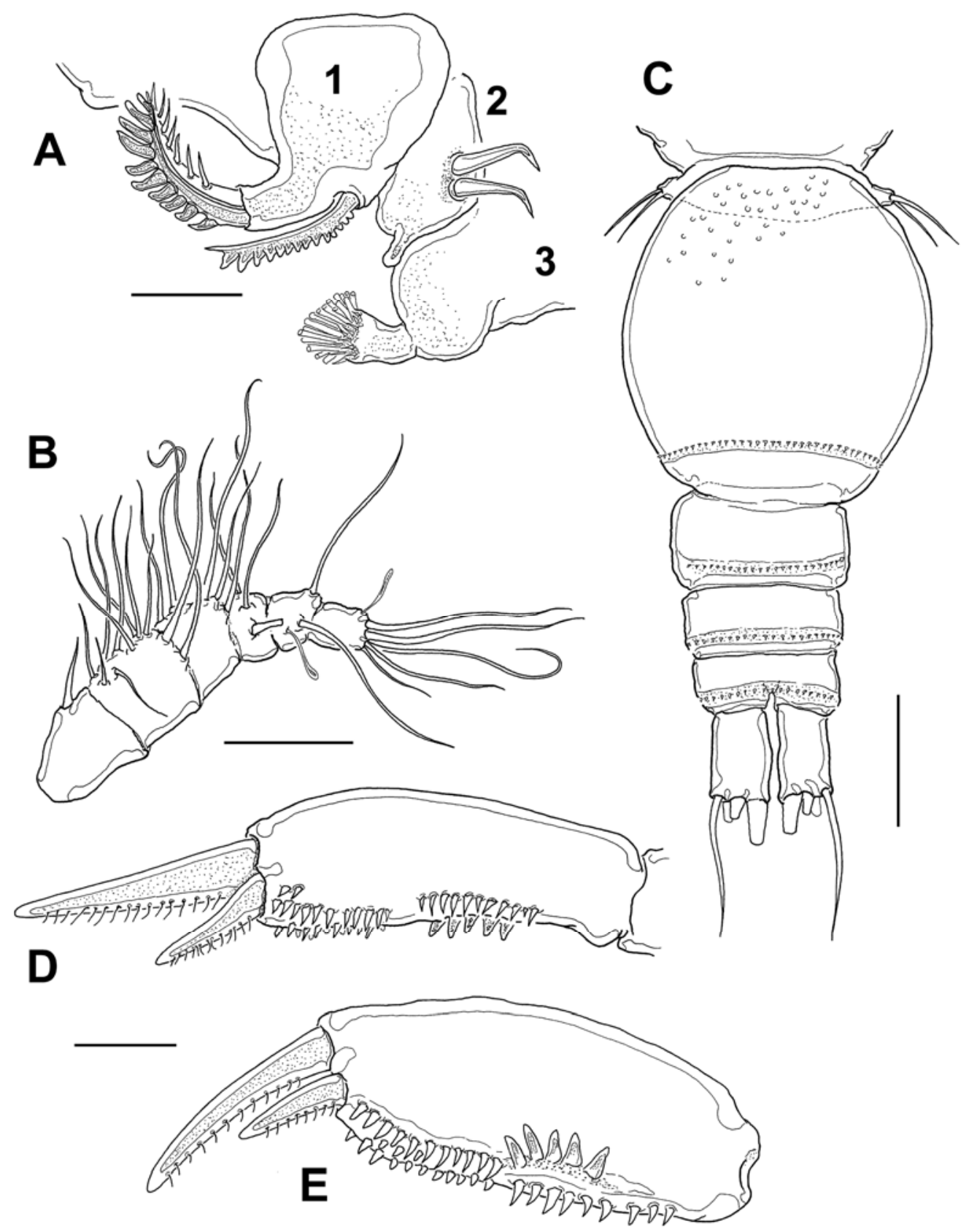

Fig. 2. Ergasilus davidi sp. n., adult female. A - mouthparts, 1 - mandible, 2 - maxillule, 3 - maxilla; $\mathbf{B}$ - antennule; $\mathbf{C}$ - urosome, ventral view; $\mathbf{D}$ - second endopodal segment of first leg, holotype; $\mathbf{E}$ - same of another specimen, showing a variant ornamentation. Scale bars: A, D = 25 $\mu \mathrm{m} ; \mathrm{B}=50 \mu \mathrm{m} ; \mathrm{C}=100 \mu \mathrm{m}$.

of characters that includes: endopod of first leg with two segments, endopod of fourth leg with three segments, and first antennulary segment with a single seta. Boxshall et al. (2002) stated that the possession of a first leg with a 2-segmented endopod, as in the new species, is an apomorphy shared by 24 known species of Ergasilus. Further, out of this group of species, only half of them have also a 2-segmented endopod on the fourth swimming legs; these 12 species are listed by Boxshall et al. (2002). Because this character (2-segmented fourth leg endopod) is not present in the new species, we compared its morphology with the remaining group of species with 2-segmented first leg endopod and 3segmented fourth leg endopod.

According to Boxshall et al. (2002) and Tavares and Luque (2005), the 12 species sharing this combination of characters include eight neotropical forms known from South America: E. argulus Cressey, 1970, E. caraguatatubensis Amado et Rocha, 1995, E. colomesus Thatcher et Boeger, 1983, E. cyanopictus Carvalho, 

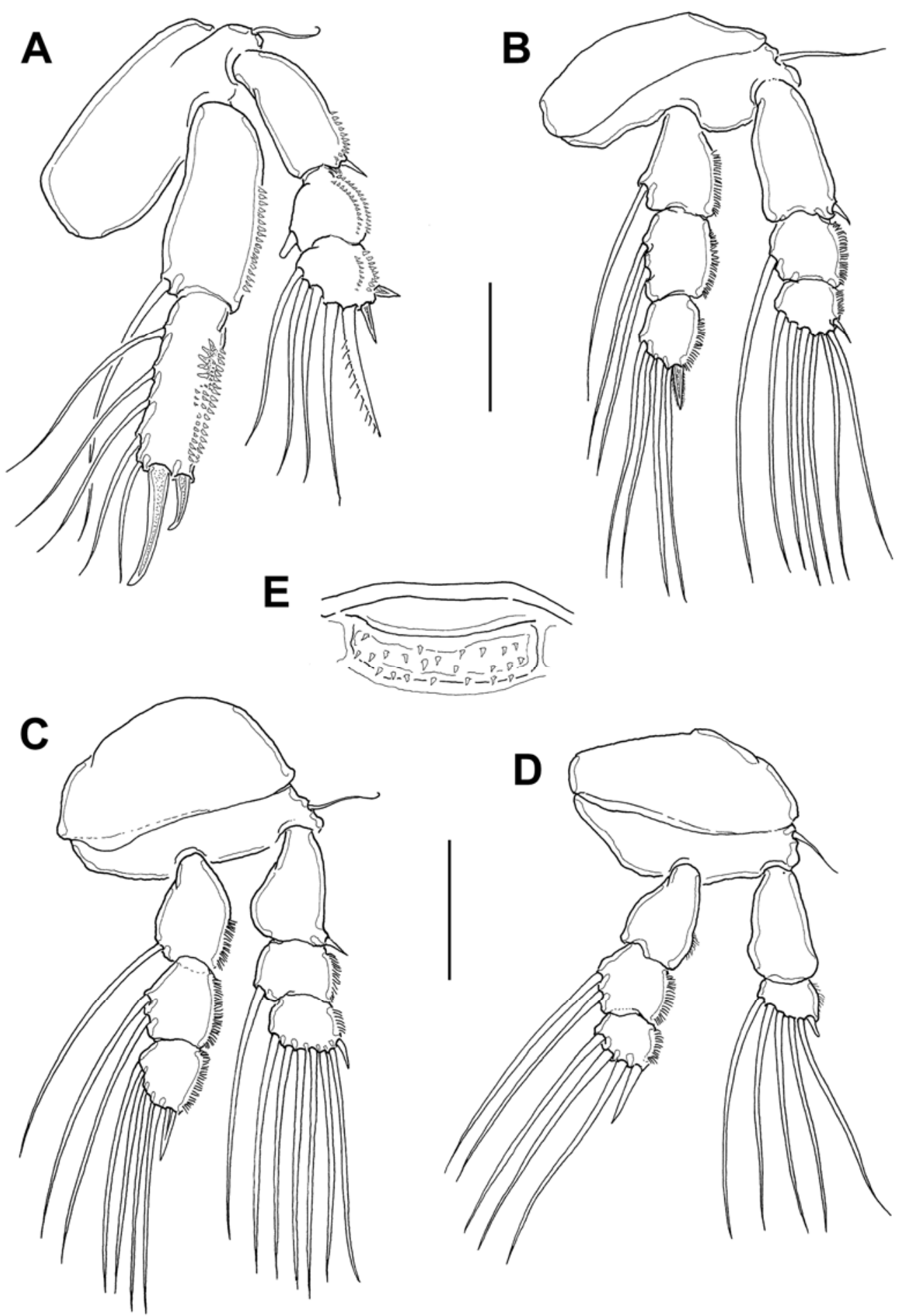

Fig. 3. Ergasilus davidi sp. n., adult female. A - first swimming leg; $\mathbf{B}$ - second swimming leg; $\mathbf{C}$ - third swimming leg; $\mathbf{D}$ - fourth swimming leg; $\mathbf{E}$ - coxal plate of second leg. Scale bars: A-E $=50 \mu \mathrm{m}$.

1962, E. ecuadorensis El-Rashidy et Boxshall, 2002, E. foresti Boxshall, Araujo et Montú, 2002, E. pitalicus Thatcher, 1984, and E. youngi Tavares et Luque, 2005. The group includes also five North American species: E. cerastes Roberts, 1969, E. chautauquensis Fellows, 1887, E. clupeidarum Johnson et Rogers, 1972, E. megaceros Wilson, 1914, and E. versicolor Wilson, 1911.

When compared with the closest North American species, E. davidi is particularly similar to E. cerastes, parasitic on freshwater catfishes; among other characters, they share the same general armature of legs and 
the presence of a rosette-like array of blunt spinules on the first endopod of the first swimming leg. In fact, when following Roberts' (1970) key for the identification of North American Ergasilus, the new species keys down to E. cerastes mainly by the presence of a prominent conical tooth on the inner margin of the third antennal segment (Fig. 1C). However, E. cerastes differs from the new species in the armature of the first antennulary segment, with 3 setae rather than one in $E$. davidi, in the presence of a tooth-like process on thesecond antennal segment, this element being smaller and inserted in a different position in the new species, in the relative length of the fourth antennal segment, which is 0.6-0.7 as long as the third segment (Roberts 1969, $1970)$ vs. $0.4-0.5$ in E. davidi, in the ornamentation of the mandibular blades (symmetrically denticulate in $E$. cerastes vs. foliose, curved elements arranged in relatively irregular pattern in the new species), and in the armature of the maxilla (with normal spinules vs. mixed pattern of blunt elements and acute spinules). Among the South American species compared herein, the new species has also some important affinities with the Brazilian species $E$. foresti, including the proportions of the antennal segments and the presence of a prominent conical process on proximal position, the distal inner setae of the second endopodal segment being shorter than the proximal setae, and the presence of a rosettelike arrangement of spiniform elements on the same segment (see Boxshall et al. 2002). However, both species differ in the general proportions of the body (narrow prosome in E. foresti vs. a wide, robust prosome in the new species), in the structure of the first endopodal segment of first legs (with expanded inner margin vs. normal condition in E. davidi), in the armature of the antennule $(1,11,5,4,2+1 \mathrm{ae}, 7+1 \mathrm{ae}$ in E. foresti vs. $1,11,5,3,2+1$ ae, $5+1$ ae) and in the armature of the second antennal segment (a curved, blunt-ended inner spine in E. foresti, whereas this element is low, not curved in the new species). The size, structure and position of this element distinguish the new species also from other three South American species, E. ecuadorensis, E. cyanopictus, and E. youngi. In the former species the process is on the proximal third of the segment, not on the distal third as in E. davidi; also, it is acute, not blunt as in the new species (El-Rashidy and Boxshall 2002). In E. cyanopictus, E. youngi, and E. versicolor this process is medial (see Roberts 1970, El-Rashidy and Boxshall 2002, Tavares and Luque 2005). Also, the general shape of the prosome, narrow in E. youngi, inflated, violin-shaped in E. ecuadorensis and E. cyanopictus (El-Rashidy and Boxshall 2002, Tavares and Luque 2005), and medially constricted in E. versicolor (Roberts 1970), diverges from the morphology of the new species. Further, E. ecuadorensis has a genital somite armed with several (8) transverse rows of strong spines (El-Rashidy and Boxshall 2002) whereas this somite has a single row of spinules in E. davidi; also, the apical spines of E. ecuadorensis are clearly shorter and stronger than in E. davidi; their proportional lengths are also different. Additional characters useful to identify this new species include a maxillar basis armed with blunt teeth, distally bent maxillular setae, and naked margins of first exopodal segments of legs 2-4.

\section{DISCUSSION}

In all cases the parasites were attached to the gills, which are the main site of infection among the ergasilids (Roberts 1970, Boxshall and Montú 1997). An infection by Ergasilus sp. in the two fish species examined herein was reported by Violante-González et al. (2007) from Tres Palos, another coastal lagoon of the Mexican Pacific. It is probable that these records are referable to Ergasilus davidi. Further, the difference of the infection prevalence and intensity between the fishes from Tres Palos is similar to the values reported herein, with a higher prevalence in Lutjanus argentiventris (58.3\% in Tres Palos vs. $42 \%$ in this survey) and lower in Centropomus robalito $(29.8 \%$ vs. $11 \%$ in this survey). The intensity of infection also agrees with our results for L. argentiventris (205 \pm 133 in Tres Palos vs. $192.7 \pm 168.2$ in Chantuto-Panzacola) and C. robalito $(5.3 \pm 9.2$ in Tres Palos vs. $2.3 \pm 2.6$ in ChantutoPanzacola). Violante-González et al. (2007) reported the occurrence of Ergasilus sp. on at least 10 other teleost species from Tres Palos, including mainly fresh and brackish water forms. It is expected that the taxonomic analysis of these specimens will provide valuable information about the parasitic fauna of Mexico and the Eastern Pacific region.

There are only a few records of species of Ergasilus from Mexico, with E. versicolor recorded from the striped mullet Mugil cephalus in Baja California (Valles-Ríos et al. 2000). The record of E. versicolor from the zooplankton of Chantuto-Panzacola (AlvarezSilva et al. 2006) is assignable to E. davidi. Many reports of ergasilids from Mexico and Central America are published as Ergasilus sp. (Fitzsimmons 2000, Violante-González and Aguirre-Macedo 2007), probably concealing the occurrence of other genera; for instance, El-Rashidy and Boxshall (1999) reported several species of Acusicola Cressey et Collette, 1970 from Honduras, Costa Rica, Panama, and from different localities of Mexico. El-Rashidy and Boxshall (2001) reported a species of Paraergasilus Markevich, 1837 from two species of freshwater fishes in Mexico. The parasitic copepod fauna is yet to be studied in Mexico and Central America.

Acknowledgements. Ana María Torres-Huerta, Universidad del Mar, Campus Puerto Angel, Oaxaca kindly allowed us to examine copepod material and provided the necessary support to develop this survey. This study was supported by a grant (CHIS-2005-C03-106) from the Comisión Nacional de Ciencia y Tecnología, State Government of Chiapas, Mexico. 


\section{REFERENCES}

Alvarez-Silva C., Miranda-Arce G., Delara ISSASI G., GÓMEZ-AGUIRRE S. 2006: Zooplancton de los sistemas estuarinos de Chantuto y Panzacola, Chiapas en época de secas y lluvias. Hidrobiológica 16: 175-182.

Amado M.A.P., Ho J.-S., RocHA C.E. 1995: Phylogeny and biogeography of the Ergasilidae (Copepoda, Poecilostomatoida), with reconsideration of the taxonomic status of Vaigamidae. Contrib. Zool. 65: 233-243.

AMADO M.A.P., ROCHA C.E. 2001: Useful characters in identifying copepods of the genus Ergasilus from plankton, with the description of male and female of E. sergipensis n. sp. Hydrobiologia 450: 149-157.

Boxshall G.A., Araujo H.M.P., Montú M. 2002: A new species of Ergasilus Nordmann, 1832 (Copepoda, Ergasilidae) from Brazil. Crustaceana 75: 269-276.

BOXSHALL G.A., HALSEY S.H. 2004: An Introduction to Copepod Diversity. The Ray Society, London, 966 pp.

Boxshall G.A., MONTÚ M.A. 1997. Copepods parasitic on Brazilian coastal fishes: a handbook. Nauplius 5: 1-225.

Bush G.A., LAFFERTY K.D., LOTZ J.M., SHOSTAK A.W. 1997: Parasitology meets ecology on its own terms: Margolis et al. revisited. J. Parasitol. 83: 575-583.

EL-RASHIDY H.H., BOXShALL G.A. 1999: Ergasilid copepods (Poecilostomatoida) from the gills of primitive Mugilidae (grey mullets). Syst. Parasitol. 42: 161-186.

EL-RASHIDY H.H, BOXSHALL G.A. 2001: Biogeography and phylogeny of Paraergasilus Markevich, 1937 (Copepoda: Ergasilidae) with descriptions of two new species from the gills of grey mullet. J. Nat. Hist. 35: 1807-1819.

EL-RASHIDY H.H., BOXSHALL G.A. 2002: New species and new records of Ergasilus Nordmann (Copepoda: Ergasilidae) from the gills of grey mullet (Mugilidae). Syst. Parasitol. 54: $37-$ 58.

FAJER-Ávila E.J., GARcÍA-VÁSQUEZ A., PlascenSIA-GONZÁLEZ H., Ríos-SiCAIROS J., GARCíA L.M., BETANCOURT M. 2006: Copepods and larvae of nematodes parasiting the white mullet Mugil curema (Valenciennes, 1836): indicators of anthropogenic impacts in tropical coastal lagoons? Environ. Monit. Assess. 122: 221-237.

FitzSIMMONS K. 2000: Tilapia aquaculture in Mexico. In: B.A. Costa-Pierce and J.E. Rakocy (Eds.), Tilapia Aquaculture in the Americas, Vol. 2. The World Aquaculture Society, Baton Rouge, Louisiana, United States, pp. 171-183.
HEwITT G.C. 1978: Abergasilus amplexus gen. et sp. nov. (Ergasilidae; parasitic Copepoda) from fishes in Lake Ellesmere, New Zealand. N.Z. J. Mar. Freshwater Res. 12: 173-177.

Ho J.-S., JAYARAJAN P., RADHAKRISHNAN S. 1992: Copepods of the family Ergasilidae (Poecilostomatoida) parasitic on coastal fishes of Kerala, India. J. Nat. Hist. 26: 1227-1241.

LIN C.-L., Ho J.-S. 1998: Two species of ergasilid copepods parasitic on fishes cultured in brackish water in Taiwan. Proc. Biol. Soc. Wash. 11: 15-27.

Moravec F., SANTANA-PiÑERos A.M., GonZÁlez-Solís D., TORRES-HUERTA A.M. 2007: A new species of Spirophilometra (Nematoda: Philometridae) from the yellowfin snook Centropomus robalito (Osteichthyes) in southern Mexico. Folia Parasitol. 54: 215-219.

ROBERTS L.S. 1969: Ergasilus cerastes sp. n. (Copepoda: Cyclopoida) from North American catfishes. J. Parasitol. 55: 1266-1270.

ROBERTS L.S. 1970: Ergasilus (Copepoda: Cyclopoida) - revision and key to species in North America. Trans. Am. Microsc. Soc. 89: 134-161.

TAVARES L.E.R., LUQUE J.L. 2005: Ergasilus youngi sp. nov. (Copepoda, Poecilostomatoida, Ergasilidae) parasitic on Aspistor luniscutis (Actinopterygii, Ariidae) from off the State of Rio de Janeiro, Brazil. Acta Parasitol. 50: 150-155.

THATCHER V.E., BOEGER W.A. 1983: The parasitic crustaceans of fishes from the Brazilian Amazon. 4. Ergasilus colomesus n. sp. (Copepoda: Cyclopoida) from an ornamental fish Colomesus asellus (Tetraodontidae) and aspects of its pathogenicity. Trans. Am. Microsc. Soc. 102: 371-379.

THATCHER V.E., BOEGER W.A. 1984: The parasitic crustaceans of fishes from the Brazilian Amazon. 9. Ergasilus callophysus sp. n. (Copepoda: Cyclopoida) from Callophysus macropterus. Proc. Helminthol. Soc. Wash. 51: 326-330.

VAlles-Ríos M.E., Ruiz-CAMPos G., GAlaviz L. 2000: Prevalencia e intensidad parasitaria en Mugil cephalus (Pisces: Mugilidae) del Rio Colorado, Baja California, México. Rev. Biol. Trop. 48: 498-501.

Violante-GonzÁlez J., Aguirre-Macedo M.L. 2007: Metazoan parasites of fishes from Coyuca Lagoon, Guerrero, Mexico. Zootaxa 1531: 39-48.

Violante-GonzÁlez J., AguirRe-Macedo M.L., MendozAFRANCO E. 2007: A checklist of metazoan parasites of fish from Tres Palos Lagoon, Mexico. Parasitol. Res. 102: 151161.

Accepted 4 April 2008 